\title{
Süreç Yönetimi ve Süreç İyileştirmenin İşletme Performansına Etkilerinin Analizi (Analysis of the Effects of Process Management and Process Improvement on Business Performance)
}

\section{Mustafa ÖZAN (iD) a}

a İstanbul Gelişim Üniversitesi, Uygulamalı Bilimler Yüksek Okulu Lojistik Yönetimi Bölümü, İstanbul, Türkiye. mozan@gelisim.edu.tr

\begin{tabular}{ll}
\hline MAKALE BILGISI & ÖZET \\
\hline Anahtar Kelimeler: & $\begin{array}{l}\text { Amaç - Bu çalışma ile süreç yönetimi, süreç iyileştirmenin işletme performansına etkileri, ayrıca demografik } \\
\text { değişkenlerle; süreç yönetimi, süreç iyileştirme ve işletme performansı arasındaki ilişkinin analiz edilmesi } \\
\text { amaçlanmıştır. }\end{array}$
\end{tabular}

Süreç İyileştirme

İşletme Performansı

Gönderilme Tarihi 3 Mart

2021

Revizyon Tarihi 16 Mayıs

2021

Kabul Tarihi 5 Haziran

2021

Makale Kategorisi: Araştırma Makalesi

Yöntem - Bu çalışma kapsamında, niceliksel teknikler kullanılarak, sebep-sonuç ilişkisini ortaya koyabilecek bir anket uygulaması yapılarak araştırma verileri elde edilmiştir. Elde edilen veriler; faktör analizleri, güvenilirlik analizi, anova analizi ve regresyon analizleri yardımıla SPSS istatistik programları ile çalışmanın amacına uygun hipotezler incelenmiştir. İstanbul ilinde yer alan Gıda lojistiği ve tedarik faaliyetlerini sürdürmekte olan 474 kişi araştırmanın örneklemini oluşturmuştur.

Bulgular - Bu çalışma için yapılan regresyon denklemi incelendiğinde: süreç tanımlama 1 birim arttı̆̆ zaman finansal olmayan performansında 0,156 birim arttığı; ölçme 1 birim arttığ 1 zaman finansal olmayan performansında 0,231 birim arttığı; yönetme 1 birim arttığ 1 zaman finansal olmayan performansında 0,187 birim arttığı; iyileştirme 1 birim arttı̆̆ zaman finansal olmayan performansında 0,314 birim arttığı tespit edilmiştir.

Tartışma - Bu çalışmada, süreç yönetimi ve süreç iyileştirmenin işletme performansına etkilerinin ortaya konulması önem taşımaktadır. Süreç, bir ya da birden fazla girdinin işletme dışında veya içinde yer alan müşteriler için birer çıkış yolu sağlayan, girdilerin de daha çok çıktıya dönüştürülebilmesine imkan tanıyan faaliyetlerdir. İşletmelerin rekabet ortamında avantaj elde edebilmeleri ve işletme çerçevesinde yapılacak faaliyetlere odaklanabilmeleri için süreç yönetimine önem vermeleri gerekir. Dolayısıyla bu çalışmanın, süreç yönetimi ile süreç iyileştirmelerinin işletmelerin performansına etkilerini ortaya koyabileceği ve literatüre katkı sağlayabileceği düşünülmektedir.

\section{ARTICLE INFO ABSTRACT}

Keywords:

Process Management Process Improvement Business Performance

Received 3 March 2021 Revised 16 May 2021 Accepted 5 June 2021

Article Classification: Research Article
Purpose: With this study, process management, the effects of process improvement on business performance, also with demographic variables; It is aimed to analyze the relationship between process management, process improvement and business performance.

Design/methodology/approach - Within the scope of this study, research data will be obtained by applying a questionnaire that can reveal the cause-effect relationship using quantitative techniques. The data obtained; With the help of factor analysis, reliability analysis, anova analysis and regression analysis, the hypotheses suitable for the purpose of the study were examined with SPSS statistical programs. The sample of the study consisted of 474 people who carry out Food logistics and procurement activities in Istanbul.

Results: When the regression equation for this study is examined: When the process definition increases by 1 unit, non-financial performance increases by 0.156 units; When measurement increases by 1 unit, nonfinancial performance increases by 0.231 units; when management increased by 1 unit, non-financial performance increased by 0.187 units; It has been determined that when improvement increases by 1 unit, non-financial performance increases by 0.314 units.

Discussion: In this study, it is important to reveal the effects of process management and process improvement on business performance. Processes are activities that provide a way out for customers outside or inside the enterprise for one or more inputs, and enable the inputs to be converted into more outputs. Businesses need to give importance to process management in order to gain advantage in the competitive environment and to focus on activities to be carried out within the framework of the business. Therefore, this study is thought to reveal the effects of process management and process improvements on the performance of enterprises and contribute to the literature. 


\section{GİRIŞ}

İşletmeler, kar elde etmeyi ve sürekli şekilde sürdürülebilir bir büyümeyi amaçlamaktadır. İşletmelerin bu amacına ulaşmalarını sağlayan unsurlar ise maliyet, müşterilerin memnuniyeti ve kaliteli hizmet oranı olmaktadır. Fiyat düzeyi rekabet ortamında belirlenirken maliyetler ise işletmelerin genel süreçleri içinde şekillenmektedir. Bunun yanı sıra müşteri memnuniyeti de söz konusu süreçlerin ve çıktıların müşterileri tatmin etme düzeyi ile alakalı olmaktadır. Süreçler, müşterilerden sipariş alınmasıyla başlayarak siparişin teslimatıyla biten aşamalardan meydana gelmektedir. İşletmeler, zincir halkalarına benzetilirse bütün halkaların her biri bir süreci temsil etmektedir. İşletmelerin performans düzeylerini artırabilmeleri için arada bulunan zayıf halkaların güçlendirilmesi gerekmektedir. Söz konusu bu zayıf halkaların güçlendirilmesi de sürecin aksamakta olan yönlerinin belirlenerek ortadan kaldırılması ile mümkün olmaktadır. Bu zayıf halkaların belirlenerek ortadan kaldırılması ise süreç iyileştirme ile gerçekleşmektedir. Süreç kavramıyla süreç iyileştirilmesi bir arada incelendiğinde, değer kavramı ortaya çıkmaktadır. İşletmeler bakımından süreçlerde meydana gelen değer; maliyet, hız, kalite ve çıtılarda iyileştirmeler anlamına gelmektedir. İşletme kapsamında değer yaratılması ise müşterilerin memnuniyetinin sağlanması ile sonuçlanmaktadır (Kaygusuz ve Kaygusuz, 2014: 33).

Süreç yönetimi işletmelerin; kalite, müşteri memnuniyeti, yenilik, maliyet ve zamandan meydana gelen değer zincirlerinin amaçlanan kontrolü için gerçekleştirilmiş olan bütün denetleyici ve düzenleyici önlemlerdir. İşletmelerin temel işlevlerini uygulayabilmek amaciyla, ihtiyaç duyulabilecek olan süreçlerin performanslarını devam ettirebilmek ve süreçlerin müşterilerle işletmelerin ihtiyaçlarını karşıladığına emin olabilmek için yapılmaktadır. İş süreç performans düzeyinin, işletmelerin başarı düzeyleri üzerinde önemli bir etkisi bulunmaktadır. Bu süreçlerin sahip oldukları başarıları da zaman içinde kaybetmemeleri, kararlı olmaları da büyük önem taşımaktadır. Bu kapsamda süreç performans düzeylerinin kalıcı olabilmesini sağlayan teknikler de süreç iyileştirme yöntemleri olmaktadır. İşletmelerin kendi performanslarını yükseltebilmeleri amaciyla üstün performans sergileyen diğer işletmeleri incelemesi, bu işletmelerin iş yapma şekillerini analiz etmesi gerekmektedir. Dolayısıyla süreç yönetimi ve süreç iyileştirmeleri sonucunda işletmelerin de performansı artmaktadır (Şahin, 2002: 7).

İşletmelerin ilk olarak, müşterilerin beklentilerini ve isteklerini anlayarak buna göre hizmetlerini ve ürünlerini şekillendirmeleri gerekmektedir. İşletmelerin hem dış hem de iç müşterilerine en iyi mal ya da hizmeti sunmaları amaçlanmaktadır. Aynı zamanda işletmelerin elde bulunan kaynaklarını en iyi şekilde kullanarak kaliteyi yakalamak için çaba sarf etmeleri de gerekmektedir. Süreç yönetiminin ihtiyaç duyulması da bu noktada kendini hissettirmektedir. Süreç yönetimi ile farklı koşullara hızlı bir şekilde uyum sağlanabilmesi, müşterilerin gereksinimlerine anında cevap verilebilmesi, ürüne ve üretime değer katılabilmesi, rekabette kalıcı olunabilmesi ve sektör içinde uzun yıllar faaliyetlerini sürdürebilmesi gibi pek çok hedefin başarılmasını sağlamaktadır (Kayışkan, vd., 2018: 913).

İşletme performansının yapısı çok boyutludur. Bu çok boyutlu yapı içince yalnızca işletme hissedarları ile ortaklarının beklentilerinin ve çıkarlarının tatmin edilmesi, işletmelerin gelecekleri için yeterli olmamaktadır. İşletme performansının sağlanabilmesi için, hem müşterilerin hem de çalışanların memnuniyetlerinin de sağlanması gerekmektedir. İşletmelerin tamamı, belli amaç ve hedefleri gerçekleştirebilmek amacıyla kurulmaktadır. Performans da bu kapsamda belirlenmiş olan amaç ve hedeflere ulaşma düzeyinin ölçümünü ortaya koymaktadır. Bu kapsamda süreçlerin en iyi şekilde yönetilmesi ve süreçlerde iyileştirmeler yapılması sonucunda işletme performansı da artmaktadır (A ğca ve Tunçer, 2006: 191). Bu çalışmada süreç yönetimi, süreç iyileştirmenin işletmelerin performansına etkileri analiz edilmiştir.

\section{KAVRAMSAL ÇERÇEVE}

\subsection{Süreç Yönetimi ve Süreç İyileştirme}

Girdilerin çıktılara dönüştürüldüğü aşamaların tamamına süreç denilmektedir. Yalnızca üretim kapsamında bakıldığında süreç kavramı, eldeki malzemelerin ürünlere dönüştürülebildiği aşama olarak görülmektedir. Süreç aynı zamanda, işletmelerde müşteri ve tedarikçi bileşenlerinin kapsam dişında tutulması anlamına da gelmektedir. Müşterilerden sipariş gelmesi ile başlayarak siparişin teslimat edilmesinin sağlanması ile biten bütün aşamalar süreci meydana getirmektedir (Karaca, 2003: 10). 


\subsubsection{Süreç Yönetimi Kavramı}

İşletmelerin var olan bütün süreçlerinin en ince ayrıntısına kadar belirlenmesi, tanımlanarak doküman haline getirilmesi, süreç sorumluları ve sahiplerinin belirlenerek performans göstergesinin oluşturulması, performansın izlenerek süreçlerin iyileştirilmesi ve kontrolünün yapılması, süreç yönetimi olarak tanımlanabilmektedir. İşletmelerin süreç yönetimi ile birlikte başarı yakalamaları, söz konusu yönetim şeklinin içselleştirerek devamlı geliştirebilir ve uygulanabilir olmasıyla gerçekleştirilebilir. Devamlı olarak gelişimin ve değişimin var olduğu rekabet ortamında işletmelerin, söz konusu değişimle doğru orantıda kendilerini geliştirmeleri yeniliklere açık olarak söz konusu düzene de ayak uydurmaları gerekmektedir (Bozkurt, 2003: 8).

\subsubsection{Süreç İyileştirme Kavramı}

İşletmeleri meydana getiren süreçlere has olmayıp bütün seviyeler için gerekli olan kavramlardan biri de sürekli iyileştirmedir. Sürekli iyileştirme kavramıyla iş geliştirme kapsamında neticeye değil sürece odaklanmak söz konusudur. Sürece odaklanma düşüncesi, süreci meydana getiren faaliyetlere odaklanılmasını ifade etmektedir. İşletmelerin rakip işletmelere göre daha rekabetçi bir güç olmasını sağlamakta olan strateji silahlarından biri de sürekli iyileştirme olmaktadır. Sürekli iyileştirme alanındaki çalışmaların, var olan yöntemlerin ve uygulamaların sürekli geliştirilmesi yanında işletmelerin yeniliklere de cesaretlendirilmesi gerekmektedir. Süreç iyileştirme kapsamında elde edilen sonuçların iyileştirilmesi istendiğinde, sonucu etkileyen süreçlerin de aynı anda iyileştirilmesi gerekmektedir. Süreç iyileştirilmesi için ilk adım ise sürecin ve bu süreçte bulunan faaliyetlerin tanımlanarak analiz edilmesidir (Carr ve Johansson, 1997: 36).

\subsubsection{Süreç Yönetimi ve Süreç İyileştirmenin Boyutları}

$\mathrm{Bu}$ kısımda, süreç yönetimi ve süreç iyileştirmenin boyutları olan; süreç tanımlama, belgeleme, ölçme, yönetme ve iyileştirme başlıkları irdelenecektir.

1. Süreçleri tanımlama; süreç yönetimi ve süreç iyileştirmenin ilk adımıdır. Süreçlerin tanımlanması, birincil sürecin misyonunu geliştirmeyi içermektedir. Misyon, sürecin amacını temsil etmektedir. Misyon beyanı yazıldıktan sonraki adım, şirketin vizyon beyanına geri dönmesini sağlamaktır. Birincil sürecin müşterileri, tedarikçileri ve ihtiyaçları belirlendikten sonra birincil süreçleri oluşturan ikincil süreçler belirlenmektedir (Şahin, 2002: 6).

2. Süreçleri belgeleme; süreç yönetimi ve süreç iyileştirmenin ikinci adımıdır. Bu adımın amacı, ikincil ve gerektiğinde iş süreçleri için standart işletim prosedürleri ve iş çalışma talimatları geliştirmektir. Bir iş süreci, basitçe ikincil bir sürecin bir alt sürecidir. Döngü sayımı, stokların hareketini yönetme ve teslimatları yapma birincil sürecindeki "envanterin kontrol edilmesi" ikincil sürecinin bir iş süreci olabilir (Gündüz, vd., 2020: 37).

3. Süreçleri ölçme; süreç yönetimi ve süreç iyileştirmenin üçüncü adımıdır. Bir sürecin yönetilmesi ve iyileştirilmesi için sürecin ölçülebilir özellikte olması gerekmektedir. Sürecin ölçülebilmesi için alınacak olan önlemler birincil, ikincil veya iş süreçleri için olabilir. Kalite, zamanlılık, miktar ve maliyet olmak üzere dört ana alanda ölçüm süreçlerine vurgu yapılmaktadır. Toplama sürecinde, iki ölçü toplama doğruluğu ve saatte toplanan satırlar buna örnek olarak verilebilir. Malzeme ve sarf malzemelerini edinmek için seçilen önlemler arasında; stok tükenmeleri, hizmet seviyesi, tedarikçi uygunsuzluklarının kapatılması için günler, envanter dönüşleri ve brüt yatırım marjı getirisi yer almaktadır (McNeese ve Marks, 2001: 303).

4. Süreçleri yönetme; Süreç yönetimi ve süreç iyileştirmenin dördüncü adımıdır. Bu adım, hem insanları hem de süreci yönetmeyi içermektedir. Referans noktaları ile ölçümler, faaliyetlerin gerçekleştirilmesi açısından büyük önem taşımaktadır. Her ölçümün bir standardı olması gerekmektedir. Bir standart, sürecin hangi düzeyde işlemesi gerektiğini temsil etmektedir. Standartların gerçekleştirilebilir olması gerekmekle birlikte, zamanla standartlarda iyileştirmeler yapılması da gerekmektedir (Özevren, 2000: 30).

5. Süreçleri iyileştirme; süreç yönetimi ve süreç iyileştirmenin beşinci adımıdır. Bu adımda süreçleri yeni seviyelere taşımak için çalışmalar yapılmaktadır. Gelecekte birincil sürecin ne olabileceğine dair bir vizyon geliştirmek ve vizyon üzerinde bir fikir birliği sağlanmasıyla başlamaktadır. Kıyaslama, yaratııılık ve yenilik bu adımda rol oynamaktadır (Gökalp ve Soylu, 2012: 14). 


\subsubsection{Süreç Yönetimi ve Süreç İyileştirmenin İşletme Performansına Etkileri}

Süreç yönetimi, faaliyetlerin bir sürecin parçası olarak düşünülmesini, tasarlanmasını ve uygulanmasını sağlamaktadır. Çalışanlar, bireysel faaliyetlerinin daha büyük bir şeyin parçası olduğunu anladıklarında, ortak hedeflere yönelmektedirler. Bir sürecin baştan sona açık bir tasarımı olduğunda, insanlar onu tutarlı bir şekilde uygulayabilmekte ve yöneticiler de onu disiplinli bir şekilde geliştirebilmektedir. Dolayısıyla süreç yönetimi, işletme süreçlerinin iyi tasarlanmasını, tasarımlara saygı duyulmasını ve güncel tutulmasını sağlamaktadır (Mallar, 2010: 123).

İşletmelerin son yıllarda üstünde en çok durmaları gerekli olan konulardan biri; elde bulunan kaynakların verimli, etkili ve ekonomik şekilde kullanılması ile tüketici memnuniyetinin sağlanmasıdır. Rekabet düzeyinin gün geçtikçe artması ile maliyetin işletmelerde hedef noktasında bulunması, farklı teknikleri, bileşenleri ve unsurların ön plana çıkmasına sağlamıştır. Bu bileşenler, teknikler ve unsurlardan en önemlisi ise süreçler ile süreç yönetimi uygulamaları olmaktadır. Süreçler ve süreç yönetimi uygulamaları gün geçtikçe işletmeler açısından daha da önemli hale gelmektedir. Bunun nedeni ise söz konusu bileşenlerin işletme performansı, etkinliği ve verimliliği kapsamında işletmeye katkı sağlayabilen unsurlar olmasından kaynaklanmaktadır (Korucuk ve Kü̧̈ük, 2018: 2122).

Süreçlerin iyileştirilmesi uygulamalarının başarılı olmasının temelinde, çalışan bireylerin tam katılımlarının sağlanması, sürekli iyileştirme yapılması ve müşteri odaklı olunması yatmaktadır. İşletmelerde söz konusu bu özelliklerin bulunması halinde yapılacak olan süreç iyileştirmeye yönelik çalışmaların başarılı olması kaçınılmazdır (Gore, 1999: 164).

Süreç iyileştirme kapsamında performans ölçümleri büyük önem taşımaktadır. Süreç iyileştirme ile işletmelerin performansının artırılması amaçlanmaktadır. Süreç iyileştirme içindeki işlemlerin, istisnai durumların, süreçlerin, zamanın azalması, kullanılan formların ve prosedürlerin sadeleştirilmesi süreç iyileştirme çalışmalarından beklenen bazı sonuçlar olmaktadır (Maull ve Childe, 1994: 28).

\section{2. İşletme Performansı ve Süreç İyileştirme İlişkisi}

İşletme performansı, işletmelerin rekabette avantaj kazanmaları, verimliliklerini ve etkinliklerini artırmaları açısından büyük önem taşımaktadır.

\subsection{1. İşletme Performansı Kavramı}

"İşletme performansı", işletme hedeflerinin gerçekleştirilebilmesi için gösterilen çabaların değerlendirilmesi şeklinde tanımlanmaktadır. Söz konusu kavram; belli bir görevin, fonksiyonun ya da amacın yürütülmesi veya gerçekleştirilmesi ile ilişkili olmaktadır. Bu kavram, planlanmış ve amaçlanmış etkinliklerin sonucunda elde edilen maddi ve maddi olmayan kazanımlar olarak belirlemektedir (Çivi, 2001: 29). İşletmelerin stratejik politika ve planlarını gerçekleştirmeleri, işletme performanslarının belirlenebilmesi ile ilişkili olmaktadır (Akal, 2000: 2).

\subsection{2. İşletme Performansının Önemi}

Sürdürülebilir rekabet ile verimlilik artışının üzerinde işletme performansının önemli bir etkisi bulunmaktadır. Dolayısıyla işletme performansını yüksek tutma, rekabetteki gücün artırılmasında etkili olan bir değişken şeklinde değerlendirilmektedir (Turunç ve Çelik, 2010: 163).

\subsection{3. İşletme Performansın Üst Seviyelere Taşınmanın İşletmeler Sağladığı Faydalar}

1. Maliyetlerin azaltılması ve fiyat avantajı; Maliyet, rekabet gücünün belirlenmesinde önemli bir faktördür. Bu bakımdan işletmelerin üretimdeki maliyetlerini azaltabilecek yöntemleri iyi bir şekilde uygulamaları gerekmektedir. Başarılı kalite çalışmaları, maliyet izleme ve önlemeyle maliyet konusunda önemli avantajlar yaratmaktadır. Maliyetlerin azaltılması, işletmelerin fiyat avantajıyla pazardaki konumlarını güçlendirmektedir (Büyükmirza, 1998: 336).

İşletmelerdeki kar hesaplamalarında dönem içindeki gelirler ve gelirleri sağlamak için harcanan maliyetler dikkate alınmaktadır. "Ekonomik katma değer", işletmelerin yeterli ölçüde gelir elde edip etmediklerinin anlaşılmasını sağlayan bir performans ölçüsü olarak tanımlanmaktadır. İşletmeler için ideal durum; öz kaynak ve yabancı kaynak maliyetini karşılayabilecek minimum bir vergi sonrasında net kara ulaşabilmektir (Ertuğrul, 2009: 211). 
2. İş gören devir hızını azaltma; işletme ve çalışan açısından ayrı ayrı büyük önem taşımaktadır. Yöneticilerin işletmelerdeki iş gören devir hızını düşürebilmek için; çalışanların iş bırakma nedenlerini anlamaları, iş iklimindeki verimliliği sağlamaları ve çalışanları tatmin edecek imkanlar oluşturmaları gerekmektedir. Yüksek olan "iş gören devir hızı" ise; işletmenin dışında, sosyolojik unsurlar, karlılık ve ülkedeki ekonomik durum açısından çözülmesi gereken bir sorun şeklinde ifade edilebilir (Yılmaz ve Halıcı, 2010: 97).

3. Müşteri memnuniyeti; müşterilerin bir ürünü satın almadan önceki beklentilerle satın aldıktan sonraki ürün performansı arasında olan farklılıkların değerlendirilmesi olarak tanımlanmaktadır. Müşteri memnuniyeti veya memnuniyetsizliği; hizmet ya da ürünlerin bir parçası olmamakta, müşterilerin kişisel olarak hizmet ve ürüne yükledikleri algıyı ifade etmektedir. Müşterilerin aynı hizmet veya deneyimle karşılaşmaları sonucundaki memnuniyet seviyeleri değişkenlik gösterebilmektedir (Banar ve Ekergil, 2010: 42-43).

Müşteri sadakati, gelecek zamanda hizmet veya ürünün yeniden satın alınması ya da mevcut iş ilişkilerinin sürdürülmesi şeklinde tanımlanmaktadır. Söz konusu kavram, işletmelerdeki performansın önemli bir göstergesidir. Dolayısıyla işletmelerin güvenirliği, imajı ve kurumsallığı; müşteri memnuniyeti ile sadakatinin kalıcılığını artırmaktadır (Flint vd., 2011: 219).

4. Rekabette avantaj kazanma, verimlilik ve etkinliği artırma; İşletmelerin etkin rekabet programlarını oluşturabilmeleri, performansın yükselmesinde ve doluluk oranının artmasında önemli bir rol oynamaktadır (Çetiner, 1995: 289-290). İşletmelerin performanslarını ölçmek için kullandıkları geleneksel ölçütler, finansal ölçütlerdir ve bu ölçütlerde genellikle işletmenin satışları, karlılık oranı ve piyasa değeri dikkate alınmaktadır. Global rekabet koşulları ise işletmelerin performanslarını ölçmelerinde finansal olmayan kalite, itibar, memnunluk gibi ölçütleri kullanmalarını gerektirmektedir (Yıldız, 2010: 181).

\section{YÖNTEM}

\subsection{Araştırmanın Modeli ve Hipotezleri}

Bu çalışmada, niceliksel teknikler izlenmiş ve belirlenmiş olan hipotezler arasındaki ilişkileri analiz edebilme, bilimsel tekniklerle veriler karşılaştırılmıştır. Bu çalışma ile ilgili yazından yararlanılmış ve analizler sonucunda oluşturulan istatistiksel modele aşağıda yer verilmiştir.

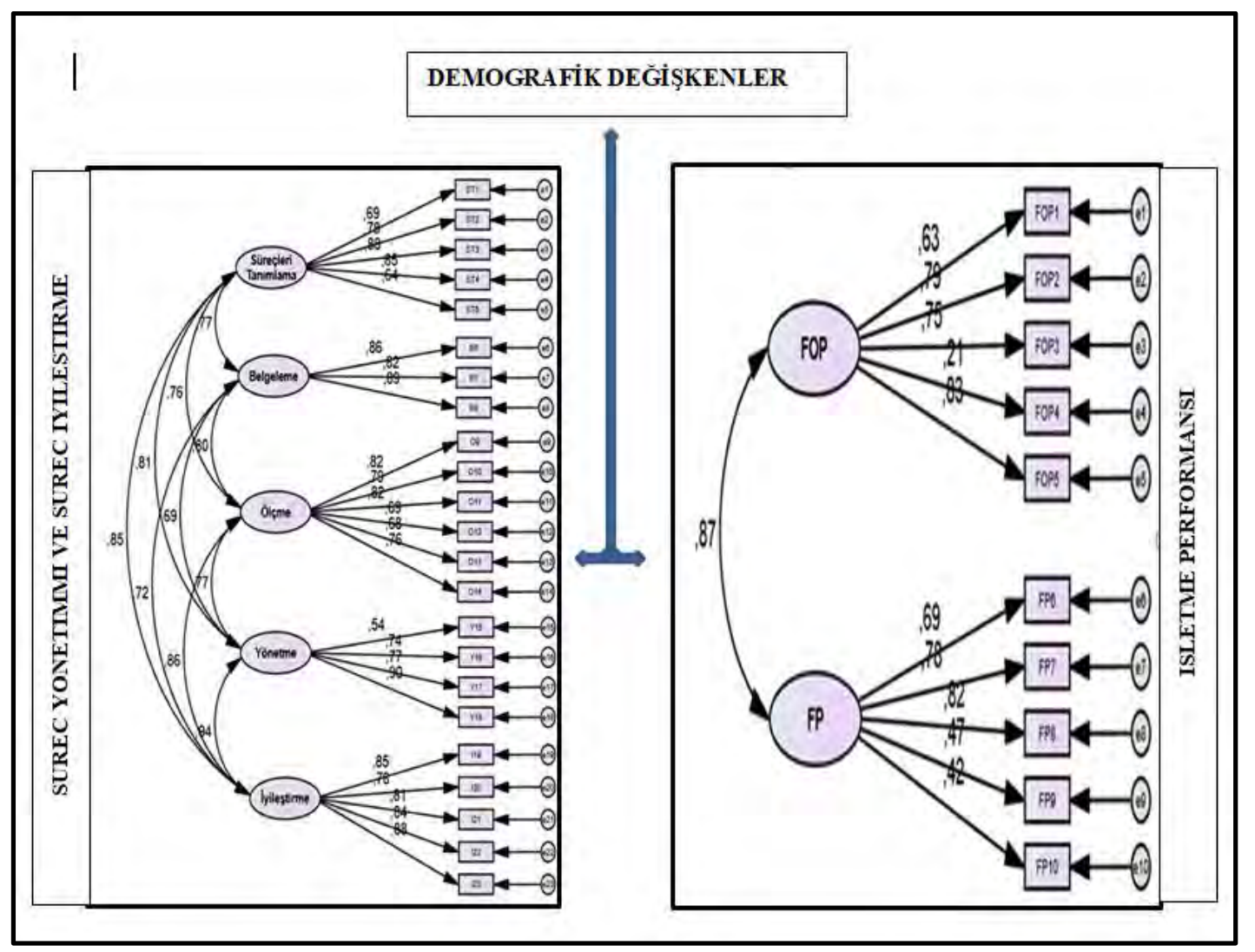

Şekil-1. Süreç Yönetimi ve Süreç İyileştirme ile İşletme Performansı için İstatiksel Model 
Şekil 1'de yer alan istatistiksel modelde, süreç yönetimi ve süreç iyileştirmenin boyutları; süreçleri tanımlama (5 madde), belgeleme ( 3 madde), ölçme (6 madde), yönetme (4 madde) ve iyileştirme olup, İşletme Performansinin boyutlarl; Finansal Olmayan Performans (FOP) (5 madde)ve Finansal Performans(FP) (5 madde) olarak yer almaktadır.

\section{Araştırmanın Hipotezleri}

Hı: Demografik değişkeleri açısından (a) süreç yönetimi, (b) süreç iyileştirme, (c) işletme performansı farklılık göstermektedir.

H1a: Cinsiyet değişkeni açısından (a) süreç yönetimi, (b) süreç iyileştirme, (c) işletme performansı farklılık göstermektedir.

Hıb: Yaş değişkeni açısından (a) süreç yönetimi, (b) süreç iyileştirme, (c) işletme performansı farklılık göstermektedir.

Hıc: Eğitim Durumu değişkeni açısından (a) süreç yönetimi, (b) süreç iyileştirme, (c) işletme performansı farklıllk göstermektedir.

$\mathrm{H}_{2}$ : Süreç yönetimi ve süreç iyileştirmeye yönelik faaliyetler, işletme performansını etkiler.

\subsection{Araștırmanın Evren ve Örneklemi}

Ana kütle büyüklüklerinin dikkate alınması suretiyle örneklem miktarının belirlenmesi için formüller ve tablolar geliştirilmiştir. Ana kütle büyüklügüne ve güvenilirliklerine göre örneklem miktarı aşağıda yer alan tabloda gösterilmiştir (Bayram, 2004: 123).

Tablo-1 Ana Kütle Büyüklügüne ve Güvenilirliklerine Göre Örneklem Miktarları

\begin{tabular}{|c|c|}
\hline Ana Kütle Büyüklüğü & $\begin{array}{c}\text { Örneklem Büyüklüklerinin Güvenilirliği } \\
\pm \% 5\end{array}$ \\
\hline 4.000 & 299 \\
\hline 5.000 & 303 \\
\hline 10.000 & 313 \\
\hline 20.000 & 318 \\
\hline 50.000 & 321 \\
\hline 100.000 & 321 \\
\hline
\end{tabular}

Not. *durumlarında evren miktarının $\% 50$ 'sinden daha fazlasının alınması gerekir.

İstanbul ilinde yer alan Gıda lojistiği ve tedariği yapan, 200 üzerinde çalışanı olan 13 adet işletmede toplam 12.565 çalışan; "Süreç Yönetimi ve Süreç İyileştirmenin İşletme Performansına Etkilerinin Analizi" başlıklı bu çalışmanın evrenini oluşturmaktadır. Bu kısımda dolayısıyla tesadüfi örnekleme tekniğinden yararlanılmıştır. Örneklem hacmi ve evren miktarının belirlenebilmesi için tablo 1 dikkate alındığında \%95 güvenilirliğe sahip ve $\% 5^{\prime}$ lik güvenilirlik sapması olacağı düşüncesi ile 20.000 kişilik evren için 318 kişinin araştırma kapsamına alınmasının yeterli olacağı görülmektedir. Yapılacak olan anketlerden bazılarının geçersiz olabileceği varsayılarak çalışmanın güvenilirliğinin sağlanması açısından 500 adet kişiye anket uygulaması yapılmasının uygun olacağına karar verilmiş ve yapılan anketlerden 26 adeti geçersiz sayılmış, 474 adet anketin geçerli kabul edilerek analizler yapılmıştır.

\subsection{Veri Toplama Araçları}

\section{Süreç Yönetimi ve Süreç İyileştirme Ölçeği ve Güvenilirlik Analizi}

Bu çalışmada, McNeese ve Marks'un (2001) geliştirmiş olduğu daha sonrasında Selimoğlu'nun (2005) kullanmış olduğu "Süreç Yönetimi ve Süreç İyileştirme Ölçeği”nden yararlanılmıştır. Söz konusu ölçek; süreçleri tanımlama (5 madde), belgeleme ( 3 madde), ölçme (6 madde), yönetme (4 madde) ve iyileştirme (5 
madde) madde olmak üzere toplam 23 madde ve 5 alt boyuttan oluşmaktadır. Ölçek katılımcılarının soruları; 1=Kesinlikle katılmıyorum, 2= Katılmıyorum, 3= Kararsızım, 4= Katılıyorum, 5=Kesinlikle katılıyorum şeklinde cevap vermeleri istenmiş olan 5'li likert tipi ölçek kullanılmıştır. Ölçeğe ait Cronbach alpha katsayısı ise 0,929 olarak bulunmuştur.

\section{2. İşletme Performansı Ölçeği ve Güvenilirlik Analizi}

Bu çalışmada, Laitinen (2002: 67), Harris ve Mongiello (2001: 124) ve Philips'in (1999: 179) geliştirdiği ve daha sonrasında Özer'in (2011: 155) çalışmasında kullanmış olduğu "İşletme Performansı" ölçeğinden yararlanılmıştır. Söz konusu ölçek; finansal performans (5 madde) ve finansal olmayan performans (5 madde) olmak üzere toplam 10 madde ve 2 alt boyuttan oluşmaktadır. Ölçek katılımcılarının soruları; 1-kesinlikle katılıyorum, 2-katılıyorum, 3-kısmen katılıyorum, 4-ne katılıyorum ne katılmıyorum, 5-kısmen katılmıyorum, 6-katılmıyorum, 7-kesinlikle katılmıyorum şeklinde cevap vermeleri istenmiş olan 7'li likert tipi ölçek kullanılmıştır. Ölçeğe ait Cronbach alpha katsayısı ise 0,852 olarak bulunmuştur.

\subsection{Verilerinin Analizi}

Bu çalışma kapsamında; niceliksel yöntemler ile neden-sonuç ilişkisini ortaya koymayı hedefleyen anket uygulaması yapılarak veri elde edilmiştir. Elde edilen verilerin SPSS istatistik analiz programları yardımıyla araştırma raporunun hazırlanabilmesi amacı ile güvenilirlik analizi, faktör analizi, korelasyon analizi ve regresyon analizi uygulanmıştır.

\section{BULGULAR}

Verilerin analiz edilmesinde çarpıklık ve basıklık katsayı değerlerinin normal dağılımlara uygun olduğu tespit edilmiştir. Ardından gruplar arasında karşılaştırmalar yapılabilmesi amacıyla t-testi ve f testi uygulanmıştır. Yapılan analizler neticesinde hesaplanmış olan $p$ değerlerinin 0,05 olarak bulunan alfa değerinden küçük olduğunda grupların arasında bir farklılık olduğuna karar verilir. Bu kısımda, anket yöntemiyle elde edilen veriler incelenerek gerçekleştirilen; güvenilirlik analizi, doğrulayıcı faktör analizi, demografik analizler, t-testi, korelasyon ve regresyon analizleri ile elde edilmiş olan sonuçlar incelenmiştir.

4.1. Süreç Yönetimi, Süreç İyileştirme, İşletme Performansı için Güvenilirlik Analizi ve Doğrulayıcı Faktör Analizleri

\section{Süreç Yönetimi ve Süreç İyileştirme için Güvenilirlik Analizi ve Doğrulayıcı Faktör Analizi}

Süreç Yönetimi ve Süreç İyileştirme Ölçeğini oluşturan 5 boyut ve 23 maddeden oluşan yapının uygunluğu doğrulayıcı faktör analizi (DFA) yardımı ile test edilmiştir $(\mathrm{p}<0,05)$. 


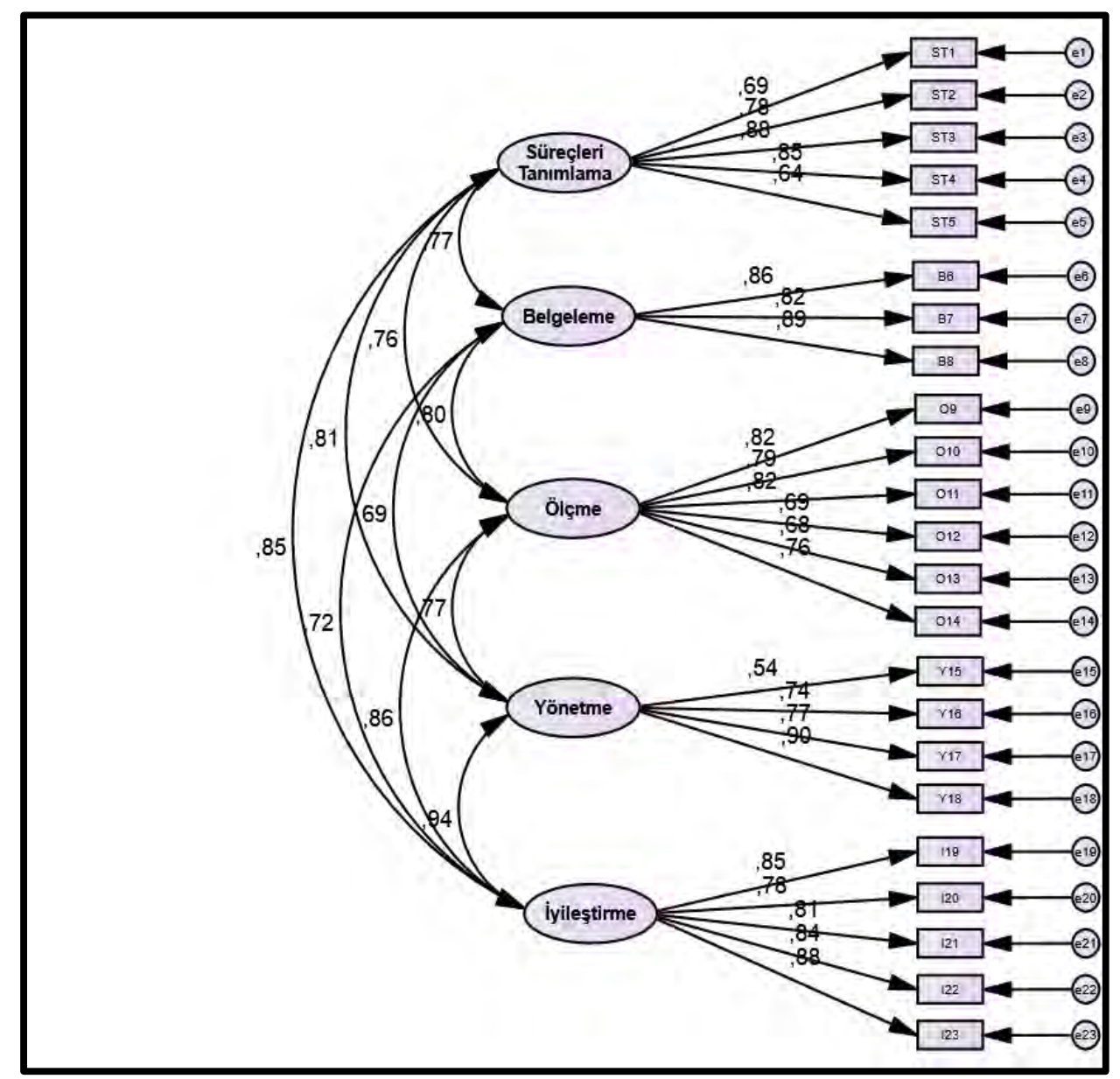

Şekil -2. Süreç Yönetimi ve Süreç İyileştirme İçin DFA

Süreç yönetimi ve süreç iyileştirme ölçeğinin uygunluğunu DFA ile test eden model şekil-2'de görüldüğü gibidir. Model süreç tanımlama, belgeleme, ölçme, yönetme ve iyileştirme olmak üzere 5 boyuttan oluşmaktadır. Modelde maddelerin boyutları açıklama yüzdesi, boyutlar arası korelasyonlar ve hata terimleri (e1, e2, e3...e23) görülmektedir.

Tablo-2 Bilişim Teknolojileri Model Uyum İndeksleri

\begin{tabular}{|l|c|c|c|}
\hline & İyi Değer & Uygun Değer & Hesaplanan Değer \\
\hline $\mathbf{X}^{2} / \mathbf{s d}$ & 3'den Küçük & 5'den Küçük & 4,910 \\
\hline RMSEA & 0,050 ve daha Düşük & 0,080 ve daha Düşük & 0,071 \\
\hline GFI & 0,90 ve Yüksek & 0,85 ve Yüksek & 0,859 \\
\hline NFI & 0,90 ve Yüksek & 0,85 ve Yüksek & 0,904 \\
\hline CFI & 0,95 ve Yüksek & 0,90 ve Yüksek & 0,917 \\
\hline
\end{tabular}

Süreç yönetimi ve süreç iyileştirme için hesaplanan Model Uyum İndeksleri tablo 2 ile birlikte verilmiştir. Hesaplanan değerlere bakıldığında model uyum indeks değerleri genel olarak uyum için iyi düzeyde olduğu görülmektedir.

\section{2. İşletme Performansı için Güvenilirlik Analizi ve Doğrulayıcı Faktör Analizi}

İşletme performansı ölçeğini oluşturan 2 boyut ve 10 maddeden oluşan yapının uygunluğu doğrulayıcı faktör analizi (DFA) yardımı ile test edilmiştir $(\mathrm{p}<0,05)$. 


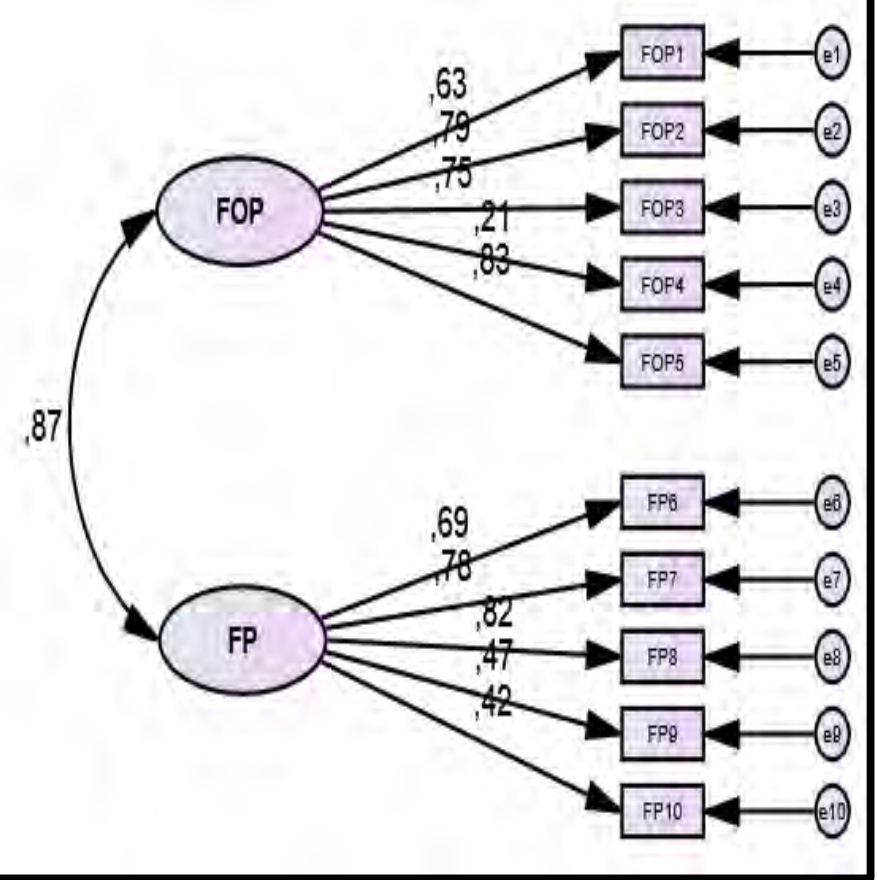

Şekil -3. Süreç Yönetimi ve Süreç İyileştirme İçin DFA

İşletme performansı ölçeğinin uygunluğunu DFA ile test eden model şekil-3'te görüldüğü gibidir. Model finansal olmayan performans (FOP) ve finansal performans(FP) olmak üzere 2 boyuttan oluşmaktadır. Modelde maddelerin boyutları açıklama yüzdesi, boyutlar arası korelasyonlar ve hata terimleri (e1, e2, e3...e23) görülmektedir.

Tablo-3 Bilişim Teknolojileri Model Uyum İndeksleri

\begin{tabular}{|l|c|c|c|}
\hline & İyi Değer & Uygun Değer & Hesaplanan Değer \\
\hline X²/sd & $3^{\prime}$ den Küçük & $5^{\prime}$ den Küçük & 4,787 \\
\hline RMSEA & 0,050 ve daha Düşük & 0,080 ve daha Düşük & 0,051 \\
\hline GFI & 0,90 ve Yüksek & 0,85 ve Yüksek & 0,929 \\
\hline NFI & 0,90 ve Yüksek & 0,85 ve Yüksek & 0,915 \\
\hline CFI & 0,95 ve Yüksek & 0,90 ve Yüksek & 0,927 \\
\hline
\end{tabular}

İşletme performansı için hesaplanan Model Uyum İndeksleri tablo 3 ile birlikte verilmiştir. Hesaplanan değerlere bakıldığında model uyum indeks değerleri genel olarak uyum için iyi düzeyde olduğu görülmektedir. 


\section{M. Özan 13/2 (2021) 1144-1161}

Tablo-4 Süreç Yönetimi ve İşletme Performansı için Tahmin Değerleri ve Güvenilirlik Katsayıları

\begin{tabular}{|c|c|c|c|c|c|}
\hline $\mathbf{z}$ & Boyut & Madde & $\begin{array}{l}\text { Tahmin } \\
\text { Değeri }\end{array}$ & $\mathbf{P}$ & $\begin{array}{l}\text { Cronbac } \\
\text { h } \alpha\end{array}$ \\
\hline \multirow{23}{*}{ 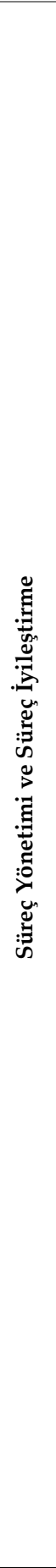 } & \multirow{5}{*}{\begin{tabular}{l|} 
Süreçleri \\
Tanımlama
\end{tabular}} & $\begin{array}{l}\text { 1. Ürün ve hizmetleri ortaya çıkaran faaliyetlerle ilgili görev tanımları açıça } \\
\text { yapılmaktadır. }\end{array}$ & ,692 & $* * *$ & \multirow{5}{*}{0,878} \\
\hline & & $\begin{array}{l}\text { 2. Belirlenen görev tanımları işletmenin daha önceden tanımlanan vizyonu } \\
\text { ile uyuşmaktadır. }\end{array}$ & ,781 & $* * *$ & \\
\hline & & $\begin{array}{l}\text { 3. Çalışanların sürecin neresinde yer aldığı ve iş yapma biçimleri açıcça } \\
\text { ortaya konmaktadır. }\end{array}$ & 884 & $* * *$ & \\
\hline & & 4. Süreçler arası ilişkiler, sınırlar ve sorumlular açıkça belirtilmektedir. & 847 & *** & \\
\hline & & $\begin{array}{l}\text { 5. Süreç akışının sağlanması için tedarik zinciri boyunca müşteri ve } \\
\text { tedarikçilerin ihtiyaçları veya beklentileri belirlenmektedir. }\end{array}$ & ,642 & $* * *$ & \\
\hline & \multirow{3}{*}{ Belgeleme } & $\begin{array}{l}\text { 6. Çalışanların iş yapma biçimleri, çalışma prosedürleri ve iş tanımları yazılı } \\
\text { olarak belirtilmekte ve sürekli güncellenmektedir. }\end{array}$ & 863 & $* * *$ & \multirow{3}{*}{0,893} \\
\hline & & $\begin{array}{l}\text { 7. Önceden belirlenmiş ve sınıflandırılmış olan süreçler dokümante } \\
\text { edilmektedir. }\end{array}$ &, 818 & $* * *$ & \\
\hline & & $\begin{array}{l}\text { 8. Tanımlanan iş yapma biçimleri için yazılı bir uygulama planı } \\
\text { geliştirilmekte ve bu uygulama planı hayata geçirilmektedir. }\end{array}$ & 886 & $* * *$ & \\
\hline & \multirow{6}{*}{ Ölçme } & 9. Süreç yönetimi uygulamalarına ilişkin referans noktaları mevcuttur. & 820 & *** & \multirow{6}{*}{0,889} \\
\hline & & $\begin{array}{l}\text { 10. Belirlenen referans noktaları ile ilgili periyodik olarak ölçümler } \\
\text { yapılmaktadır. }\end{array}$ & ,787 & $* * *$ & \\
\hline & & $\begin{array}{l}\text { 11. Mevcut süreçlerin ürün veya hizmetlere kattığı kalite faktörü ile ilgili } \\
\text { ölçümler yapılmaktadır. }\end{array}$ & 824 & $* * *$ & \\
\hline & & $\begin{array}{l}\text { 12. Ürün ve hizmetlerle ilgili bütün faaliyetlerin zamanında yapılıp } \\
\text { yapılmadığı ölçülmektedir. }\end{array}$ & ,688 & $* * *$ & \\
\hline & & $\begin{array}{l}\text { 13. Sektörde daha önceden var olan bir ürünü geliştirip yeni bir ürün olarak } \\
\text { pazara sunuyoruz. }\end{array}$ & ,682 & $* * *$ & \\
\hline & & $\begin{array}{l}\text { 14. Süreçler sonunda ortaya konan çıtıların miktarı ile ilgili ölçümler } \\
\text { yapılmaktadır. }\end{array}$ & ,757 & $* * *$ & \\
\hline & \multirow{4}{*}{ Yönetme } & $\begin{array}{l}\text { 15. Süreç işleyişi boyunca maliyetler sürekli denetlenmekte ve gereksiz } \\
\text { olanlar atılarak tasarruf sağlanmaktadır. }\end{array}$ &, 539 & $* * *$ & \multirow{4}{*}{0,811} \\
\hline & & $\begin{array}{l}\text { 16. Yöntem ve prosedürler için geliştirilen standartların kontrolü günce } \\
\text { olarak yapılmaktadır. }\end{array}$ & ,744 & $* * *$ & \\
\hline & & 17. Üst yönetim, süreç yönetimine destek vermektedir. & 774 & $* * *$ & \\
\hline & & $\begin{array}{l}\text { 18. Süreçlerin performansı düzenli olarak izlenmekte ve gerekli müdahalelet } \\
\text { yapılmaktadır. }\end{array}$ & 895 & $* * *$ & \\
\hline & \multirow{5}{*}{ İyileştirme } & 19. Süreç iyileştirme çalışmaları sürekli yapılmaktadır. & 845 & $* * *$ & \multirow{5}{*}{0,916} \\
\hline & & $\begin{array}{l}\text { 20. Süreç iyileştirme için müşteri verileri, operasyonel veriler ve dış } \\
\text { kyyaslamalar analiz edilmektedir. }\end{array}$ & ,783 & $* * *$ & \\
\hline & & $\begin{array}{l}\text { 21. Süreç iyileştirme, müşteri ve diğer paydaşları tam olarak tatmin edecek } \\
\text { biçimde yapılmaktadır. }\end{array}$ & ,808 & $* * *$ & \\
\hline & & $\begin{array}{l}\text { 22. Çalışanlar, yeni fikirler üreterek, yeni yöntemlerle iş yapma biçimlerin } \\
\text { sürekli olarak geliştirmektedirler. }\end{array}$ & 841 & $* * *$ & \\
\hline & & $\begin{array}{l}\text { 23. Süreç iyileştirme sayesinde çalışanların iş yapma yöntemlerinin kalite v€ } \\
\text { verimliliği arttırılmaktadır. }\end{array}$ & 880 & $* * *$ & \\
\hline \multirow{10}{*}{ 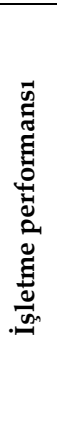 } & \multirow{5}{*}{$\begin{array}{l}\text { Finansal } \\
\text { Olmayan } \\
\text { Performans }\end{array}$} & 1. İşletmemizde müşteri memnuniyeti yüksektir. & 633 & *** & \multirow{5}{*}{0,745} \\
\hline & & 2. İşletmemizde müş̧eri sadakati yüksektir. & 793 & *** & \\
\hline & & 3. İşletmemizde işgücü memnuniyeti yüksektir. & 754 & $* * *$ & \\
\hline & & 4. İşletmemizde iş gören devir hızı düşüktür. & 206 & $* * *$ & \\
\hline & & 5. İşletmemizin kurumsal imajı güçlenmiştir. & 828 & $* * *$ & \\
\hline & \multirow{5}{*}{$\begin{array}{l}\text { Finansal } \\
\text { Performans }\end{array}$} & 6. İşletmemizin doluluk oranı yüksektir. & 692 & $* * *$ & \multirow{5}{*}{0,753} \\
\hline & & 7. İşletmemizin satışları yüksektir. & ,781 & $* * *$ & \\
\hline & & 8. İşletmemizin pazar payı yüksektir. & 815 & $* * *$ & \\
\hline & & 9. İşletmemizin maliyetleri düşüktür. & ,467 & $* * *$ & \\
\hline & & 10. İşletmemizin karı yüksektir. & ,416 & $* * *$ & \\
\hline
\end{tabular}




\section{M. Özan 13/2 (2021) 1144-1161}

Süreç Yönetimi ve Süreç İyileştirme maddelerine ait tahmin değerlerinin de oldukça yüksek değerler aldıkları görülmektedir ve ayrıca $\mathrm{p}$ değerleri incelendiğinde maddelerin açıklama oranlarının anlamlı olduğu görülmektedir $(\mathrm{p}<0,05)$. Süreç yönetimi ve süreç iyileştirme boyutlarından süreçleri tanımlama $(0,878)$, belgeleme $(0,893)$, ölçme $(0,889)$, yönetme $(0,811)$ ve iyileştirme $(0,916)$ için hesaplanan Cronbach Alfa değerinin oldukça yüksek değerler aldığı görülmektedir.

İşletme performansı maddelerine ait tahmin değerlerinin de oldukça yüksek değerler aldıkları görülmektedir ve ayrıca $p$ değerleri incelendiğinde maddelerin açıklama oranlarının anlamlı olduğu görülmektedir $(p<0,05)$. İşletme performansı boyutlarından finansal olmayan performans $(0,745)$ ve finansal performans $(0,753)$ için hesaplanan Cronbach Alfa değerinin oldukça yüksek değerler aldığı görülmektedir.

\subsection{Demografik Bulgular}

Uygulanan anket çalışması sonucunda elde edilen örneklemdeki demografik değişkenlerin dağılımları frekans analizi ile gözlemlenmiştir. Analiz sonucunda örneklemdeki gözlemlerin demografik değişkenlere göre dağılımları özetlenerek tablo haline verilmiştir.

Tablo-5 Demografik Değişkenlerin Frekans Tablosu

\begin{tabular}{|l|l|c|c|}
\hline \multicolumn{2}{|c|}{} & Frekans & Yüzde \\
\hline \multirow{4}{*}{ Cinsiyet } & Erkek & 342 & $72,2 \%$ \\
\cline { 2 - 4 } & Kadın & 132 & $27,8 \%$ \\
\hline \multirow{5}{*}{ Yaş } & $20-29$ Yaş & 150 & $31,6 \%$ \\
\cline { 2 - 4 } & $30-39$ Yaş & 174 & $36,7 \%$ \\
\cline { 2 - 4 } & $40-49$ Yaş & 120 & $25,3 \%$ \\
\cline { 2 - 4 } & 50 Yaş Üzeri & 30 & $6,3 \%$ \\
\hline \multirow{5}{*}{ Eğitim Durumu } & Lise & 84 & $22,7 \%$ \\
\cline { 2 - 4 } & Ön Lisans & 108 & $44,3 \%$ \\
\cline { 2 - 4 } & Lisans & 210 & $15,2 \%$ \\
\cline { 2 - 4 } & Lisans Üstü & 72 & $100 \%$ \\
\hline Toplam & & 474 & \\
\hline
\end{tabular}

Özetlenen tablo incelendiğinde örnekleme giren gözlemlerin 342 'sinin erkek $(\% 72,2)$ ve 132 'sinin ise kadın $(\% 27,8)$ olduğu gözlenmiştir. Yaş dağılımlarına bakıldığında 150'sinin 20-29 yaş arasında $(\% 31,6), 174$ 'ünün 30-39 yaş arasında $(\% 36,7), 120$ 'sinin $40-49$ yaş arasında (\%25,3) ve $30^{\prime}$ unun 50 yaş ve üzerinde $(\% 6,3)$ olduğu görülmektedir. Ayrıca örnekleme girenlerin 84'ü lise (\%17,7), 108'i ön lisans (\%22,8), 210'u lisans (\%44,3) ve 72 'si lisansüstü $(\% 15,2)$ düzeyinde eğitim aldığı görülmektedir.

\subsection{Demografik Özellikler ile Süreç Yönetimi, Süreç İyileştirme ve İşletme Performansı Arasındaki İlişki için T testi, One way Anova ve Post-Hoc Analizleri}

Örnekleme katılan bireylerin kişisel bilgileri ile Süreç Yönetimi ve Süreç İyileştirme ve İşletme performansı Arasındaki İlişki f testi Post-Hoc analizleri yardımıyla incelenmiştir. 


\section{M. Özan 13/2 (2021) 1144-1161}

Tablo-6 Demografik Özellikler ile Süreç Yönetimi ve Süreç İyileştirme ve İşletme Performansı için İlişki Tablosu

\begin{tabular}{|c|c|c|c|c|c|c|c|}
\hline Düzeyler & & & $\mathbf{N}$ & Ort. & f Değeri & p Değeri & $\begin{array}{l}\text { Hipotez } \\
\text { Post Hoc }\end{array}$ \\
\hline \multirow{14}{*}{ Cinsiyet } & \multirow{2}{*}{ Süreçleri Tanımlama } & Erkek & 342 & 4,2211 & \multirow{2}{*}{$-2,093$} & \multirow{2}{*}{,037 } & \multirow{2}{*}{$\begin{array}{c}\text { H1 Kabul } \\
\Delta<\mathrm{B}\end{array}$} \\
\hline & & Kadın & 132 & 4,3727 & & & \\
\hline & \multirow{2}{*}{ Belgeleme } & Erkek & 342 & 3,9357 & \multirow{2}{*}{,- 037} & \multirow{2}{*}{,970 } & \multirow{2}{*}{ H1 Red } \\
\hline & & Kadın & 132 & 3,9394 & & & \\
\hline & \multirow{2}{*}{ Ölçme } & Erkek & 342 & 3.8889 & -058 & 954 & H1 Red \\
\hline & & Kadın & 132 & 3,8939 & & & \\
\hline & Yönetme & Erkek & 342 & 4.0702 & 470 & 638 & H1 Red \\
\hline & & Kadın & 132 & 4.0341 & $4 / 0$ & ,000 & \\
\hline & İvilestirme & Erkek & 342 & 4.0351 & & & H1 Kabul \\
\hline & ryıleştirme & Kadın & 132 & 3,8273 & $2,3 / 1$ & ,018 & $\Delta>B$ \\
\hline & & Erkek & 342 & 4,0877 & & & H1 Red \\
\hline & Finansal Olmayan Performans & Kadın & 132 & 4,0909 &,- 048 &, 962 & \\
\hline & & Erkek & 342 & 3,8491 & & & H1 Kabul \\
\hline & Finansal rerrormans & Kadın & 132 & 4,1455 & $-4, / 06$ & ,000 & $A<\mathrm{B}$ \\
\hline & & 20-29 Yas & 150 & 4.3440 & & & H1 Kabul \\
\hline & Sürecleri Tanımlama & 30-39 Yas & 174 & 4,0828 & 9,613 & 000 & $\mathrm{~B}<\mathrm{A}, \mathrm{C}$ \\
\hline & & 40-49 Yas & 120 & 4.4800 & 4,013 & & $\mathrm{C}>\mathrm{B}, \mathrm{D}$ \\
\hline & & 50 Yas Üzeri & 30 & 4,0400 & & & \\
\hline & & 20-29 Yas & 150 & 3.8800 & & & \\
\hline & & 30-39 Yas & 174 & 3.7701 & & & H1 Kabul \\
\hline & Belgeleme & 40-49 Yas & 120 & 4,2000 & 5,364 & ,001 & $\mathrm{C}>\mathrm{A}, \mathrm{B}$ \\
\hline & & 50 Yas Üzeri & 30 & 4,1333 & & & \\
\hline & & 20-29 Yas & 150 & 4,2067 & & & \\
\hline & & $30-39$ Yas & 174 & 3.6207 & & & H1 Kabul \\
\hline & Olçme & 40-49 Yas & 120 & 3,9000 & 14,056 & ,000 & $\mathrm{A}>\mathrm{B}, \mathrm{C}$ \\
\hline & & 50 Yas Üzeri & 30 & 3.8333 & & & \\
\hline & & 20-29 Yas & 150 & 4.2900 & & & \\
\hline Yas & Yönetme & 30-39 Yas & 174 & 3,8017 & 16826 & 000 & H1 Kabul \\
\hline raş & Yonetme & 40-49 Yas & 120 & 4,2250 & $16,8<0$ & ,000 & $\mathrm{B}<\mathrm{A}, \mathrm{C}$ \\
\hline & & 50 Yaș Üzeri & 30 & 3,7500 & & & \\
\hline & & 20-29 Yas & 150 & 4,2560 & & & \\
\hline & İvilestirme & $30-39$ Yas & 174 & 3,6828 & 14.091 & 000 & H1 Kabul \\
\hline & ryıleştirme & 40-49 Yas & 120 & 4,0900 & 14,091 & , & $\mathrm{B}<\mathrm{A}, \mathrm{C}$ \\
\hline & & 50 Yas Üzeri & 30 & 3.8400 & & & \\
\hline & & 20-29 Yas & 150 & 4,3360 & & & \\
\hline & Finansal Olmavan Performans & 30-39 Yas & 174 & 3.9379 & 12.254 & 000 & H1 Kabul \\
\hline & & 40-49 Yas & 120 & 4,0400 & & , & $\mathrm{A}>\mathrm{B}, \mathrm{C}, \mathrm{D}$ \\
\hline & & 50 Yas Üzeri & 30 & 3.9200 & & & \\
\hline & & 20-29 Yas & 150 & 4,3840 & & & \\
\hline & & 30-39 Yas & 174 & 3,7862 & & & H1 Kabul \\
\hline & Finansal Performans & 40-49 Yas & 120 & 3.7300 & 41,423 & ,000 & $\mathrm{A}>\mathrm{B}, \mathrm{C}, \mathrm{D}$ \\
\hline & & 50 Yas Üzeri & 30 & 3,3200 & & & \\
\hline & & Lise & 84 & 4,2143 & & & \\
\hline & & ÖnLisans & 108 & 4.5333 & & & H1 Kabul \\
\hline & Sureçlerı Ianımlama & Lisans & 210 & 4.0857 & 11,866 & ,000 & $\mathrm{C}<\mathrm{B}, \mathrm{D}$ \\
\hline & & Lisans Üstü & 72 & 4.4333 & & & \\
\hline & & Lise & 84 & 4,1667 & & & \\
\hline & Belgeleme & ÖnLisans & 108 & 4.1852 & 18,017 & 000 & H1 Kabul \\
\hline & Belgeleme & Lisans & 210 & 3,5905 & 18,017 & ,000 & $C<A, B, D$ \\
\hline & & Lisans Üstü & 72 & 4,3056 & & & \\
\hline & & Lise & 84 & 4,0357 & & & \\
\hline & Ölcme & Ön Lisans & 108 & 4,0370 & 3721 & & H1 Kabul \\
\hline & Ulçme & Lisans & 210 & 3.7571 & 3,721 & ,011 & $\mathrm{C}<\mathrm{B}$ \\
\hline & & Lisans Üstü & 72 & 3,8889 & & & \\
\hline & & Lise & 84 & 4.0000 & & & \\
\hline Eğitim & Yönetme & ÖnLisans & 108 & 4.2917 & 4575 & 004 & H1 Kabul \\
\hline Durumu & & Lisans & 210 & 3.9857 & & & $\mathrm{~B}>\mathrm{A}, \mathrm{C}, \mathrm{D}$ \\
\hline & & Lisans Üstü & 72 & 4,0000 & & & \\
\hline & & Lise & 84 & 4,0286 & & & \\
\hline & İvilestirme & Ön Lisans & 108 & 4,1333 & 3.779 & 011 & H1 Kabul \\
\hline & Iyıleştırme & Lisans & 210 & 3,8343 & $3,7 / 9$ & , & $\mathrm{C}<\mathrm{B}$ \\
\hline & & Lisans Üstü & 72 & 4,1000 & & & \\
\hline & & Lise & 84 & 4.1429 & & & \\
\hline & & Ön Lisans & 108 & 4,3667 & & & H1 Kabul \\
\hline & Finansal Olmayan Performans & Lisans & 210 & 3.9029 & 13,982 & ,000 & $C<A, B, D$ \\
\hline & & Lisans Üstü & 72 & 4,1500 & & & \\
\hline & & Lise & 84 & 3.7143 & & & \\
\hline & Finansal Performans & Ön Lisans & 108 & 4,3778 & 22,373 & 000 & H1 Kabul \\
\hline & Finansal rerrormans & Lisans & 210 & 3,8686 & $22,3 / 3$ & ,000 & $\mathrm{B}>\mathrm{A}, \mathrm{C}, \mathrm{D}$ \\
\hline & & Lisans Üstü & 72 & 3,7000 & & & \\
\hline
\end{tabular}

Hıa: Cinsiyet değiş̧keni açısından (a) süreç yönetimi, (b) süreç iyileştirme, (c) işletme performansı farklılık göstermektedir. 
Süreç yönetimi ve süreç iyileştirme ve işletme performansı arasındaki ilişki için yapılan test sonucunda cinsiyet için elde edilen $p$ değerleri incelendiğinde belgeleme $(p=0,970)$, ölçme $(p=0,954)$, yönetme $(p=0,638)$ ve finansal olmayan performansın $(p=0,962)$ cinsiyete göre farklllık göstermediği görülmektedir ( $p>0,05)$. Süreçleri tanımlama $(p=0,037)$, iyileştirme $(p=0,018)$ ve finansal performans $(p=0,000)$ için hesaplanan $p$ değerleri incelendiğinde $\mathrm{H}_{1 . a}$ hipotezinin kabul edildiği ve cinsiyete göre farklılık gösterdiği tespit edilmiştir $(\mathrm{p}<0,05)$.

Hıb: Yaş değişkeni açısından (a) süreç yönetimi, (b) süreç iyileştirme, (c) işletme performansı farklılık göstermektedir.

Yaş değişkenine göre farklılıkların incelenmesi için elde edilen $\mathrm{p}$ değerleri incelendiğinde süreçleri tanımlama $(\mathrm{p}=0,000)$, belgeleme $(\mathrm{p}=0,001)$, ölçme $(\mathrm{p}=0,000)$, yönetme $(\mathrm{p}=0,000)$, iyileştirme $(\mathrm{p}=0,000)$, finansal olmayan performans $(p=0,000)$ ve finansal performans $(p=0,000)$ için $\mathrm{H} 1$ hipotezinin kabul edildiği ve yaşa göre farklılık gösterdiği gözlenmiştir $(\mathrm{p}<0,05)$.

H1c: Eğitim Durumu değişkeni açısından (a) süreç yönetimi, (b) süreç iyileştirme, (c) işletme performansı farklılık göstermektedir.

Eğitim durumuna göre farklılıkların incelenmesi için elde edilen $\mathrm{p}$ değerleri incelendiğinde süreçleri tanımlama $(\mathrm{p}=0,000)$, belgeleme $(\mathrm{p}=0,000)$, ölçme $(\mathrm{p}=0,011)$, yönetme $(\mathrm{p}=0,004)$, iyileştirme $(\mathrm{p}=0,011)$, finansal olmayan performans $(p=0,000)$ ve finansal performans $(p=0,000)$ için $H 1$ hipotezinin kabul edildiği ve eğitim durumuna göre farklıllı gösterdiği gözlenmiştir $(\mathrm{p}<0,05)$.

\subsection{Korelasyon Analizi}

Korelasyon analizi, korelasyon katsayısının (r) büyüklüğünü yorumlayarak değişkenler arasındaki ilişkinin yönünü ve büyüklük oranını belirleyen bir analiz yöntemidir. Hesaplanan $r$ değerinin mutlak büyüklügü $0<x<0,2$ arasında bir değer alıyorsa değişkenler arasındaki ilişkinin çok zayıf; $0,2<x<0,4$ arasında bir değer alıyorsa değişkenler arasındaki ilişkinin zayıf; $0,4<x<0,6$ arasında bir değer alıyorsa değişkenler arasındaki ilişkinin orta; $0,6<x<0,8$ arasında bir değer alıyorsa değişkenler arasındaki ilişkinin yüksek; $0,8<x<1,0$ arasında bir değer alıyorsa değişkenler arasındaki ilişkinin çok yüksek olduğu söylenebilir. Değer aralığından da anlaşılabileceği gibi korelasyon katsayısı -1 ile +1 arasında değerler alır ve aldığı değerler 0 yaklaştıkça değişkenler ilişkisiz, uç nokta olan -1 ve +1 değerlerine yaklaştıkça çok ilişkili şeklinde yorumlanır. Hesaplanan $r$ değerinin aldığı işaret sadece ilişkinin yönünü belirlemek amaçlı kullanılır ve ilişkinin büyüklügüne bir etkisi yoktur.

Tablo-7 Korelasyon Analizi

\begin{tabular}{|l|c|c|c|c|c|c|c|}
\hline & $\begin{array}{c}\text { Süreçleri } \\
\text { Tanılama }\end{array}$ & Belgeleme & Ölçme & Yönetme & İyileştirme & $\begin{array}{c}\text { Finansal } \\
\text { Olmayan } \\
\text { Performans }\end{array}$ & $\begin{array}{c}\text { Finansal } \\
\text { Performans }\end{array}$ \\
\hline Süreçleri Tanımlama & 1 &, $678^{* *}$ &, $675^{* *}$ &, $708^{* *}$ &, $777^{* *}$ &, $704^{* *}$ &, $570^{* *}$ \\
\hline Belgeleme &, $678^{* *}$ & 1 &, $682^{* *}$ &, $605^{* *}$ &, $640^{* *}$ &, $600^{* *}$ &, $418^{* *}$ \\
\hline Ölçme &, $675^{* *}$ &, $682^{* *}$ & 1 &, $666^{* *}$ &, $759^{* *}$ &, $714^{* *}$ &, $624^{* *}$ \\
\hline Yönetme &, $708^{* *}$ &, $605^{* *}$ &, $666^{* *}$ & 1 &, $824^{* *}$ &, $724^{* *}$ &, $680^{* *}$ \\
\hline İyileştirme &, $777^{* *}$ &, $640^{* *}$ &, $759^{* *}$ &, $824^{* *}$ & 1 &, $779^{* *}$ &, $611^{* *}$ \\
\hline $\begin{array}{l}\text { Finansal Olmayan } \\
\text { Performans }\end{array}$ &, $704^{* *}$ &, $600^{* *}$ &, $714^{* *}$ &, $724^{* *}$ &, $779^{* *}$ & 1 &, $703^{* *}$ \\
\hline Finansal Performans &, $570^{* *}$ &, $418^{* *}$ &, $624^{* *}$ &, $680^{* *}$ &, $611^{* *}$ &, $703^{* *}$ & 1 \\
\hline
\end{tabular}

"Süreç Yönetimi ve Süreç İyileştirme" ve "İşletme performansı" arasındaki korelasyon katsayıları incelendiğinde genel olarak pozitif yönlü iyi ilişkilere sahip olduğu görülmektedir. Değişkenler arasındaki en yüksek ilişkinin iyileştirme ve yönetme arasında olduğu görülmektedir ( $r=824)$. Benzer şekilde finansal olmayan performans ile iyileştirme arasındaki r değerinin 0,779 olduğu görülmektedir. Bu değere bakarak finansal olmayan performans ile iyileştirme arasında pozitif yönlü yüksek bir ilişki olduğu söylenebilir. Yani değişken değerleri beraber artış veya beraber azalış göstermektedir. Bu bağlamda değişkenlerden hangisinin diğerini etkilediğini tespit edebilmek için regresyon analizi yapılmasına karar verilmiştir. 


\subsection{Regresyon Analizi}

Bir veya birden fazla bağımsız değişkenin bir bağımlı değişken üzerindeki etkilerini inceleyen ve çok değişkenli analiz yöntemlerinden birisi olan regresyon analizi, değişkenler arasındaki doğrusal ilişkilerin yönünü ve büyüklügünü incelerken regresyon denklemi adı verilen bir model denklem kullanır. Bu denklem $Y=\beta_{0}+\beta_{i} X_{i}+\varepsilon_{i}$ şeklinde ifade edilebilir. Denklemde yer alan $X_{i}$ i. bağımsız değişkeni, $Y$ bağımlı değişkeni, $\beta_{i} i$. bağımsız değişkene ait katsayıyı, $\varepsilon_{i}$ ise i. bağımlı değişkene sahip hata terimlerini ve $\beta_{0}$ sabit katsayı değerini temsil etmektedir. Hata terimlerinin toplamları da $0^{\prime}$ dır.

\section{Süreç Yönetimi ve Süreç İyileştirmenin İşletme performansına Etkileri}

Tablo-8 Süreç Yönetimi ve Süreç İyileştirmenin İşletme performansı Üzerindeki Etkisi

\begin{tabular}{|l|c|c|c|c|c|c|}
\hline & \multicolumn{2}{|c|}{ Finansal Olmayan Performans } & \multicolumn{3}{|c|}{ Finansal Performans } \\
\hline & B (Beta) & $\mathbf{t}$ Değeri & $\begin{array}{c}\mathbf{p} \\
\text { Değeri }\end{array}$ & B (Beta) & $\mathbf{t}$ Değeri & p Değeri \\
\hline Sabit Katsayı & 1,149 & 10,246 &, 000 &, 892 & 6,084 &, 000 \\
\hline Süreçleri Tanımlama &, 156 & 3,390 &, 001 &, 160 & 2,941 &, 003 \\
\hline Belgeleme &, 023 &, 571 &, 568 &,- 201 & $-4,262$ &, 000 \\
\hline Ölçme &, 231 & 5,168 &, 000 &, 390 & 7,408 &, 000 \\
\hline Yönetme &, 187 & 3,865 &, 000 &, 519 & 9,097 &, 000 \\
\hline İyileştirme &, 314 & 5,387 &, 000 &,- 109 & $-1,584$ &, 114 \\
\hline
\end{tabular}

$\mathrm{H}_{2}$ : Süreç yönetimi ve süreç iyileştirmeye yönelik faaliyetler, işletme performansını etkiler.

Yapılan analiz sonucunda belgelemenin $(p=0,568)$ finansal olmayan performans üzerinde etkisinin bulunmadığı tespit edilmiştir ( $p>0,05)$. Sabit katsayı $(p=0,000)$, Süreçleri tanımlama $(p=0,001)$, ölçme $(p=0,000)$, yönetme $(p=0,000)$ ve iyileştirmenin $(p=0,000)$ finansal olmayan performans üzerinde etkisinin anlamlı olduğu gözlenmiştir $(\mathrm{p}<0,05)$. Elde edilen sonuçlar ile kurulacak olan regresyon denklemine ilişkileri anlamlı bulunan değişkenler alınarak anlamsız olanlar ise denklemden çıkartılacaktır.

Elde edilecek denklemin teorik yapısı $Y=\beta_{0}+\beta_{1} X_{1}+\beta_{2} X_{2}+\beta_{3} X_{3}+\beta_{4} X_{4}$ şeklinde olacaktır. Bu denklemde kullanılan sembollerin anlam ve karşılıkları aşağıdaki regresyon sembollerinin karşılıkları tablosunda verilmiştir.

Tablo-9 Regresyon Sembollerinin Karşılıkları

\begin{tabular}{cll}
\hline Semboller & Anlamları & Karşılık Gelen Kavram/Değer \\
\hline $\mathbf{Y}$ & Bağımlı Değişken & Finansal Olmayan Performans \\
\hline $\mathbf{X}_{1}$ & Bağımsız Değişken & Süreçleri Tanımlama \\
\hline $\mathbf{X}_{2}$ & Bağımsız Değişken & Ölçme \\
\hline $\mathbf{X}_{3}$ & Bağımsız Değişken & Yönetme \\
\hline $\mathbf{X}_{4}$ & Bağımsız Değişken & İileştirme \\
\hline$\beta_{0}$ & Sabit Katsayı & 1,149 (Tablodaki B değerlerinden) \\
\hline$\beta_{1} ; \beta_{2} ; \beta_{3} ; \beta_{4}$ & Bağımsız Değişkene ait Katsayı & 0,$156 ; 0,231 ; 0,187 ; 0,314$ \\
\hline
\end{tabular}

Regresyon sembollerinin karşılıkları tablo 9'da verilen sembol karşılıkları ve değerler denklemde yerine koyulursa denklemin son hali aşağıdaki gibi olacaktır.

Finansal Olmayan Performans = 1,149 + 0,156 Süreçleri tanımlama + 0,231 Ölçme + 0,187 Yönetme + 0,314 iyileştirme

Regresyon denklemine bakarak süreç tanımlama 1 birim arttığı zaman finansal olmayan performansında 0,156 birim artacağı söylenebilir. Yani süreçleri tanımlamanın finansal olmayan performans üzerinde \%15,6 oranında pozitif yönlü bir etkisi olduğu söylenebilir. Ölçme 1 birim arttığı zaman finansal olmayan performansında 0,231 birim artacağ1 söylenebilir. Yani ölçmenin finansal olmayan performans üzerinde \%23,1 oranında pozitif yönlü bir etkisi olduğu söylenebilir. Yönetme 1 birim arttığı zaman finansal olmayan performansında 0,187 birim artacağı söylenebilir. Yani yönetmenin finansal olmayan performans üzerinde \%18,7 oranında pozitif yönlü bir etkisi olduğu söylenebilir. İyileştirme 1 birim arttığı zaman finansal olmayan 
performansında 0,314 birim artacağı söylenebilir. Yani iyileştirmenin finansal olmayan performans üzerinde \%31,4 oranında pozitif yönlü bir etkisi olduğu söylenebilir.

Finansal Performans için yapılan analiz sonucunda iyileştirmenin $(\mathrm{p}=0,114)$ finansal olmayan performans üzerinde etkisinin bulunmadığı tespit edilmiştir $(p>0,05)$. Sabit katsayı $(p=0,000)$, Süreçleri tanımlama $(\mathrm{p}=0,003)$, belgelemenin $(\mathrm{p}=0,000)$ ölçme $(\mathrm{p}=0,000)$ ve yönetmenin $(\mathrm{p}=0,000)$ finansal performans üzerinde etkisinin anlamlı olduğu gözlenmiştir $(\mathrm{p}<0,05)$. Elde edilen sonuçlar ile kurulacak olan regresyon denklemine ilişkileri anlamlı bulunan değişkenler alınarak anlamsız olanlar ise denklemden çıkartılacaktır.

Finansal Performans =0,892 +0,160 Süreçleri tanımlama - 0,201 Belgeleme + 0,390 Ölçme + 0,519 Yönetme

Regresyon denklemine bakarak süreç tanımlama 1 birim arttığı zaman finansal performansın 0,160 birim artacağ1 söylenebilir. Yani süreçleri tanımlamanın finansal performans üzerinde $\% 16,0$ oranında pozitif yönlü bir etkisi olduğu söylenebilir. Belgeleme 1 birim arttığı zaman finansal performansın 0,201 birim azalacağı söylenebilir. Yani belgelemenin finansal performans üzerinde \%20,1 oranında negatif yönlü bir etkisi olduğu söylenebilir. Ölçme 1 birim arttığı zaman finansal performansın 0,390 birim artacağı söylenebilir. Yani ölçmenin finansal performans üzerinde \%39,0 oranında pozitif yönlü bir etkisi olduğu söylenebilir. Yönetme 1 birim arttığı zaman finansal performansın 0,519 birim artacağı söylenebilir. Yani yönetmenin finansal performans üzerinde $\% 51,9$ oranında pozitif yönlü bir etkisi olduğu söylenebilir.

\section{TARTIŞMA VE SONUÇ}

Bu kısımda çalışmada yapılan analizlerin sonuçları ile daha önce yapılan araştırmalarda elde edilen sonuçlara yer verilmiştir:

Bu çalışmada, cinsiyet durumu ile süreç yönetimi ve süreç iyileştirme ve işletme performansı arasındaki ilişki için yapılan test sonucunda ortalamalar incelendiğinde; kadınların süreçleri tanımlama ve finansal performans düzeylerinin erkeklere göre daha düşük olduğu gözlenmiştir. Ancak iyileştirme süreçlerinde kadınların erkeklere oranla daha başarılı bir ortalamaya sahip olduğu tespit edilmiştir. Diğer bir anlatımla cinsiyet ile ilgili analizler sonucunda; süreçleri tanımlama, iyileştirme ve finansal performans için hesaplanan p değerleri incelendiğinde ( $<<0,05)$; H1a hipotezinin kabul edildiği ve cinsiyete göre farklılık gösterdiği tespit edilmiştir. Keleş'in (2010: 77) yaptığı çalışmada ise; süreç yönetimine yönelik uygulamalara katılımcıların durumlarına göre demografik özellikler ile iş tatminleri ilişkilendirildiği belirlenmiştir. Söz konusu çalışmada, çalışanların süreç yönetimi alanındaki uygulamalara katılımları incelenmiş ve cinsiyet ile çalışanların birim unsurlarının süreç yönetimi üzerinde önemli bir etkisi bulunmazken; eğitim durumları, yaş, kurumda çalışma süreleri, toplam çalışma süreleri ile arasında anlamlı bir farklılık olduğu tespit edilmiştir. Öneri olarak, İşletmeler cinsiyet farkı gözetmeksizin; süreç iyileştirme ve süreç yönetimi ilgili çalışmalar yapmalı, malzeme ve bilgi yönetimini merkezde tutulmall, işletmeleri bütün teknolojik gelişmelerle adapte edilebilecek uygulamaları sürekli hale getirmeli ve sürdürülebilir rekabet avantajını sağlayabilecek yenilikleri yapılmalıdır.

$\mathrm{Bu}$ çalışmada, yaş değişkenine göre farklılıkların incelenmesi için yapılan test sonucunda ortalamalar incelendiğinde; 40-49 yaş arasında bulunan bireylerin süreç tanımlama, belgeleme, iyileştirme alanlarında 3039 yaş arasında olan bireylere göre daha iyi olduğu gözlenmektedir. Ayrıca 30-39 yaş arasında olan bireylerin yönetme ve iyileştirme alanlarında 20-29 yaş arasında ve 40-49 yaş arasında olan kişilere göre daha düşük seviyede olduğu görülmektedir. 20-29 yaş arasında olan bireylerin diğer yaş guruplarına göre finansal olmayan performans ve finansal olan performans düzeylerinin daha yüksek olduğu saptanmıştır. Ayrıca, süreçleri tanımlama, belgeleme, ölçme, yönetme, iyileştirme, finansal olmayan performans ve finansal performans için H1a hipotezinin kabul edildiği ve yaşa göre farklılık gösterdiği gözlenmiştir $(\mathrm{p}<0,05)$. Kesim'in (2018: 57) çalışmasında ise; yaş, iş tecrübesi, cinsiyet ve şu an çalıştıkları kurumdaki iş tecrübelerine göre süreç iyileştirme, müşteri ile yaklaşımları ve örgütte yalın yönetim çalışmalarında istatistiksel anlamla bir farklılık olmadığı tespit edilmiştir. Dolayısıyla bu çalışmada, demografik özelliklerin süreç yönetimine herhangi bir etki etmediği sonucuna ulaşılmıştır. Çalışanların yaşı ilerledikçe deneyimin süreç yönetimi ve süreç iyileştirme alanında farklılıklara neden olabileceği, bu bağlamda çalışma hayatına yeni girmiş çalışanların performansının daha yüksek olabileceği dikkate alınmalıdır. 
$\mathrm{Bu}$ çalışmada, eğitim durumuna göre farklılıkların incelenmesi için yapılan test sonucunda ortalamalar incelendiğinde; lisans mezunlarının süreçleri tanımlama düzeylerinin ön lisans ve lisansüstü düzeyinde eğitim almış kişilere göre daha düşük olduğu gözlenmiştir. Dolayısıyla, lisans düzeyinde eğitim almış katılımcıların belgeleme ortalamalarının diğer eğitim guruplarına göre daha düşük olduğu görülmektedir. Ayrıca ön lisans düzeyinde eğitim almış katılımcıların yönetme ortalamalarının daha yüksek olduğu gözlenmiştir. Lisans mezunlarının finansal olmayan performansı diğer guruplara göre daha düşükken, ön lisans mezunlarının finansal performansı diğer gruplara göre daha yüksek olduğu tespit edilmiştir. Ayrıca, eğitim durumuna göre farklılıkların incelenmesi için elde edilen $\mathrm{p}$ değerleri incelendiğinde; süreçleri, belgeleme, ölçme, yönetme, iyileştirme, finansal olmayan performans ve finansal performans için H1a hipotezinin kabul edildiği ve eğitim durumuna göre farklılık gösterdiği gözlenmiştir $(p<0,05)$. Sevimler vd.'nin (2011: 96) yapmış olduğu çalışmada ise, eğitimle işletme performansı arasında pozitif yönlü ve anlamlı yönde bir ilişki bulunmadığı tespit edilmiştir., Çalışmada, işletme performansı ile eğitim değişkeni arasında $\% 56^{\prime}$ lık oranda doğrusal ilişki olduğu tespit edilmiştir. Dolayısıyla, işletme performansının \%56'lık kısmının eğitim değişkeni tarafından açıklandığı belirlenmiştir. İşletmelerde personelin vasıflı olması, kariyer eğitleri alması, lisansüstü eğitimini yapması gibi belirli bir alanda yetişmiş bireylerin istihdam edilmesi; süreç yönetimi, süreç iyileştirme, yeniliklere katılım performansının daha yüksek olabileceği dikkate alınmalıdır.

$\mathrm{Bu}$ çalışma için yapılan regresyon analizi sonucunda; süreç yönetimi ve süreç iyileştirmenin; finansal olmayan performans üzerinde pozitif yönlü bir etkisinin olduğu tespit edilmiştir. Ayrıca regresyon denklemi incelendiğinde:

- Süreç tanımlama 1 birim arttığı zaman finansal olmayan performansında 0,156 birim arttığı,

- Ölçme 1 birim arttı̆̆ı zaman finansal olmayan performansında 0,231 birim arttığı,

-Yönetme 1 birim arttı̆̆ zaman finansal olmayan performansında 0,187 birim arttığı,

- İyileştirme 1 birim arttığı zaman finansal olmayan performansında 0,314 birim arttığı tespit edilmiştir. İpçioğlu ve Kahya'nın (2016: 198) çalışmasında ise; finansal performans ile finansal olmayan performansın arttırılması için bilginin uygulanması, dönüştürülerek korunması, işletme süreçlerinin geliştirilmesi, etkin şekilde yönetilmesi, örgütsel süreçler ile uygulamalara entegre edilmesi gerektiği vurgulanmıştır. Çalışmadan elde edilen sonuçlarda; otomotiv yan sanayi işletmelerinde bilgilerin elde edilmesi süreçlerinin etkin işlemediği belirlenmiştir. Dolayısıyla öneri olarak, işletmelerin çevreye yönelik iyileştirme alanında yapılacakları finansal olmayan çalışmalar, işletmelerin performansını artırabilmektedir. Bu amaçla, işletmeler; tedarikçilerden, müşterilerden vb. gibi pek çok paydaştan bilgi edinme süreçlerini ve araçlarını geliştirerek, özellikle de işletme dışından bilgi edinebilmek amacı işbirliği çalışmalarını arttırmalıdır.

$\mathrm{Bu}$ çalışma için yapılan regresyon analizi sonucunda; süreç iyileştirme ve süreç yönetiminin, finansal performans üzerinde pozitif yönlü bir etkisinin olduğu tespit edilmiştir. Ayrıca regresyon denklemi incelendiğinde;

- Süreç tanımlama 1 birim arttığı zaman finansal performansın 0,160 birim arttığı,

- Ölçme 1 birim arttığı zaman finansal performansın 0,390 birim arttığı,

-Yönetme 1 birim arttığı zaman finansal performansin 0,519 birim arttığı,

- Belgeleme 1 birim arttığı zaman finansal performansın 0,201 birim azalacağ tespit edilmiştir. Öznaz'ın (2013: 162) yapmış olduğu çalışmada ise; süreç yapılandırma ve süreç iyileştirme yolu ile işletmelerde operasyonel verimsizliklerin giderilmesi, maliyetlerin ve ürün hatalarını azaltabilmek, rekabet gücünü ve finansal performansı arttırıcı etkiler sağladığı sonucuna ulaşılmıştır. Amaçlarına uygun olan iş süreçleri ile müşterilerin beklenti ve isteklerini karşılayan ürünlerin üretilmesinde, üretin maliyetlerinin azaltılmasında, çalışan motivasyonun arttırılmasında, finansal göstergelerin ve işletme performansının arttırılmasında olumlu gelişmeler sağlanabileceği belirlenmiştir. Özellikle yönetmenin finansal performans üzerindeki pozitif etkisi düşünülürse yönetme alanında yapılacak olan faaliyetlere özen gösterilmesi finansal performansın artırmada fayda sağlayacaktır. Gereğinden fazla belgeleme karışıklığa sebebiyet vereceğinden bu alanda yapılacak olan sadeleştirme ve kolaylıklar sayesinde finansal performansı da artabilir. 


\section{KAYNAKLAR}

Ağca, V. ve Tunçer, E. (2006). Çok Boyutlu Performans Değerleme Modelleri ve Bir Balanced Scorecard Uygulamas1, Afyon Kocatepe Üniversitesi, İ.̇.B.F. Dergisi, 8(1), 173-193.

Akal, Z. (2000). İşletmelerde Performans Ölçüm ve Denetimi, Çok Yönlü Performans Göstergeleri, Ankara: Milli Prodüktivite Merkezi Yayınları, No: 473.

Banar, K. ve Ekergil, V. (2010). Muhasebe Meslek Mensuplarının Hizmet Kalitesi: Sunulan Hizmetlerin Kalitesi ile Müşteri Memnuniyeti İlişkisi, Anadolu Üniversitesi Sosyal Bilimler Dergisi, 10(1), 39-60.

Bayram, N. (2004). Sosyal Bilimlerde SPSS ile Veri Analizi, Bursa: Ezgi Kitabevi.

Bozkurt, R. (2003). Süreç İyileştirme, 3. Basım, Ankara: MPM Yayınları No: 661.

Büyükmirza, K. (1998). Maliyet ve Yönetim Muhasebesi, Ankara: Barış Yayınevi.

Carr, D. K. and Johansson, H. J. (1997). Best Practices in Reengineering, New York: Mc Graw Hill.

Çetiner, E. (1995). Konaklama İşletmelerinde Yönetim Muhasebesi, Ankara: Tubitay Ltd. Şti.

Çivi, E. (2001). Rekabet Gücü: Literatür Araştırması, Yönetim ve Ekonomi: Celal Bayar Üniversitesi İktisadi ve İdari Bilimler Fakültesi Dergisi, 8(2), 21-38.

Ertuğrul, M. (2009). Değere Dayalı Performans Ölçüsü Olarak Ekonomik Katma Değerin Kuramsal Temelleri: Dünyada ve Türkiye' de Uygulamaları, Dumlupınar Üniversitesi Sosyal Bilimler Dergisi, 0(24), 207-218.

Flint, D. J., Blocker, C. P. and Boutin Jr, P. J. (2011). Customer Value Anticipation, Customer Satisfaction and Loyalty: An Empirical Examination, Industrial Marketing Management, 40(2), 219-230.

Gore, Jr, E. W. (1999). Organizational Culture, TQM, and Business Process Reengineering An Empirical Comparison, Team Performance Management: An International Journal, 5(5), 164-170.

Gökalp, B. ve Soylu, B. (2012). Tedarikçinin Süreçlerini İyileştirme Amaçlı Tedarikçi Seçim Problemi, Endüstri Mühendisliği Dergisi, 23(1), 4-15.

Gündüz, M. Ö., Gültekin, F. ve Kürtül, İ. (2020). OIC/SMIIC Standartları Çerçevesinde Helal Gıda Üretimi ve Helal Belgelendirme Süreçleri, Akademik Platform Helal Yaşam Dergisi, 2(1), 36-43.

Haris, P. ve Mongiello, M. (2001). Key Performance Indicators in European Hotel Properties: General Manager's Choices and Company Profiles. International Journal of Contemporary Hospitality Management, 13(3), 120-127.

İpçioğlu, İ. ve Kahya, D. (2016). Bilgi Yönetimi Sürecinin Örgütsel Performansa Etkisi ve Otomotiv Sektöründe Bir Araştırma, Süleyman Demirel Üniversitesi Sosyal Bilimler Enstitüsü Dergisi, 3(25), 179-204.

Karaca, K. Y. (2003). Türkiye'de Kamu İktisadi Teşebbüslerinin Etkinlik Ölçümü Üzerine Bir Uygulama Sosyal Bilimler Enstitüsü, Yayımlanmamış Yüksek Lisans Tezi, Ankara.

Kaygusuz, Y. ve Kaygusuz, S. (2014). Süreç İyileştirmenin İşletme Performansına Etkileri, Paradoks Economics, Sociology and Policy Journal, 10(02), 31-50.

Kayiskan, D., Asan, H. and Ozveri, O. (2018). Improving Process Management of Supply Management Activities In Paintıng Sector, Journal of Mehmet Akif Ersoy University Economics And Administrative Sciences Faculty, 5(3), 913-924.

Keleş, N. (2010). Süreç Yönetimi Uygulamalarına Katılım ile İş Tatmini ve Örgüte Bağlllık İlişkisi: Bir Kamu İşletmesi Üzerine Araştırma, Marmara Üniversitesi, Sosyal Bilimler Enstitüsü, Yayımlanmamış Yüksek Lisan Tezi, İstanbul.

Kesim, Ş. (2018). Hemşirelik Hizmetlerinde Süreç Yönetimi ve Diyabet Hemşireliği Üzerine Bir Araştırma, İstanbul Arel Üniversitesi, Sosyal Bilimler Enstitüsü, Yayımlanmamış Yüksek Lisan Tezi, İstanbul.

Korucuk, S. ve Küçük, O. (2018). Gıda İşletmelerinde Süreç Yönetimi Uygulamalarının İşletme Performansına Etkisi: Erzurum'da Bir Uygulama, Hitit Üniversitesi Sosyal Bilimler Enstitüsü Dergisi, 11(3), 2122-2136. 
Laitinen, E.K. (2002). A Dynamic Performance Measurement System: Evidence From Small Finish Technology Companies, Scandinavian Journal of Management, 18 (1), 65-69.

Mallar, M. Á. (2010). Process Management: an Effective Management Approach, Visión de Futuro, 13(1), 111126.

Maull, R. and Childe, S. (1994). Business Process Re-engineering: An Example from the Banking Sector, International Journal of Service Industry Management, 5(3), 26-34.

McNeese, W. and Marks, C. (2001). The Power of Process Management, In ASQ World Conference on Quality and Improvement Proceedings, American Society for Quality, 300-311.

Özer, Ö. (2011). Kurumsal Girişimcilik ve İşletme Performansı İlişkisi: Dört ve Beş Yıldızlı Otel İşletmelerinde Uygulama, Dokuz Eylül Üniversitesi, Sosyal Bilimler Enstitüsü, Yayımlanmamış Doktora Tezi, İzmir.

Özevren, M. (2000). Toplam Kalite Yönetimi Temel Kavramlar ve Uygulamalar, 2. Baskı, İstanbul: Alfa Basım Yayımları.

Öznaz, D. (2013). Hazır Giyim İşletmelerinde Süreç Yönetimi ve Süreç Performansının Optimizasyonu, Marmara Üniversitesi, Fen Bilimleri Enstitüsü, Yayımlanmamış Doktora Tezi, İstanbul.

Phillips, P.A. (1999). Performance Measurement Systems and Hotels: A New Conceptual Framework. International Journal of Hospitality Management, 18(2), 171-182.

Selimoğlu, N. (2005). Süreç Yönetimi ve Süreç İyileştirmede Bilgi Yönetiminin Rolü ve Uygulamaya İlişkin Bir Araştırma, İstanbul Üniversitesi, Sosyal Bilimler Enstitüsü, Yayımlanmamış Yüksek Lisans Tezi, İstanbul.

Sevimler, S., Duran, C. ve Çetindere, A. (2011). Toplam Kalite Yönetiminin Unsurları ile İşletme Performansı Arasındaki İlişkinin İncelenmesi: Eskişehir Örneği, Dumlupınar Üniversitesi Sosyal Bilimler Dergisi, (29), $87-100$.

Şahin, H. (2002). Proses Tabanlı Kalite Yönetim Sistemi, 1. Baskı, Ankara: Polimer Matbaacılık.

Turunç, Ö. ve Çelik, M. (2010). Örgütsel Özdeşleşme ve Kontrol Algılamalarının, Çalışanların İşten Ayrılma Niyeti ve İş Performansına Etkileri, Atatürk Üniversitesi İktisadi ve İdari Bilimler Dergisi, 24(3), 163-181.

Yıldız, S. (2010). İşletme Performansının Ölçümü Üzerine Bankacılık Sektöründe Bir Araştırma, Erciyes Üniversitesi İktisadi ve İdari Bilimler Fakültesi Dergisi, 36, 179-193.

Yılmaz, B. ve Halıcı, A. (2010). Işgücü Devir Hızını Etkileyen Etmenler: Sekreterlik Mesleğinde Bir Araştırma, Uluslararası İktisadi ve İdari İncelemeler Dergisi, 2(4), 93-108. 